Article

\title{
Effects of $\mathrm{Sm}_{2} \mathrm{O}_{3}$ and $\mathrm{V}_{2} \mathrm{O}_{5}$ Film Stacking on Switching Behaviors of Resistive Random Access Memories
}

\author{
Jian-Yang Lin ${ }^{1, *}$, Kuang-Yao $\mathrm{Wu}^{2} \mathbb{D}$ and Kai-Huang Chen ${ }^{3, *}$ \\ 1 Department of Electronic Engineering, National Yunlin University of Science and Technology, Douliou, \\ Yunlin 640, Taiwan \\ 2 Graduate School of Engineering Science and Technology, National Yunlin University of Science and \\ Technology, Douliou, Yunlin 640, Taiwan; s71818@gmail.com \\ 3 Department of Digital Game and Animation Design, Tung Fang Design University, No.110, Dongfang Rd., \\ Hunei Dist., Kaohsiung City 82941, Taiwan \\ * Correspondence: linjy@yuntech.edu.tw (J.-Y.L.); d9131802@gmail.com (K.-H.C.)
}

Received: 18 April 2019; Accepted: 10 June 2019; Published: 19 June 2019

\begin{abstract}
In this work, the resistive switching characteristics of resistive random access memories (RRAMs) containing $\mathrm{Sm}_{2} \mathrm{O}_{3}$ and $\mathrm{V}_{2} \mathrm{O}_{5}$ films were investigated. All the RRAM structures made in this work showed stable resistive switching behavior. The High-Resistance State and Low-Resistance State of Resistive memory $\left(\mathrm{R}_{\mathrm{HRS}} / \mathrm{R}_{\mathrm{LRS}}\right)$ ratio of the RRAM device containing a $\mathrm{V}_{2} \mathrm{O}_{5} / \mathrm{Sm}_{2} \mathrm{O}_{3}$ bilayer is one order of magnitude higher than that of the devices containing a single layer of $\mathrm{V}_{2} \mathrm{O}_{5}$ or $\mathrm{Sm}_{2} \mathrm{O}_{3}$. We also found that the stacking sequence of the $\mathrm{Sm}_{2} \mathrm{O}_{3}$ and $\mathrm{V}_{2} \mathrm{O}_{5}$ films in the bilayer structure can affect the switching features of the RRAM, causing them to exhibit both bipolar resistive switching (BRS) behavior and self-compliance behavior. The current conduction mechanisms of RRAM devices with different film structures were also discussed.
\end{abstract}

Keywords: resistive random access memory (RRAM); bipolar resistive switching behavior; thin films; electrical conduction mechanism

\section{Introduction}

As technology continues to advance, electronic products have become indispensable items in peoples' lives. For electronic products, memory capacity has a key impact on electronic computing speed and efficiency. Due to their superior features, such as simple structure, low power consumption, high-speed operation, small device area, and nonvolatile properties, resistive random access memories (RRAMs) have attracted extensive attention for next-generation nonvolatile memory applications [1,2]. Several transition metal oxides (TMOs) such as $\mathrm{ZnO}, \mathrm{TiO}_{2}, \mathrm{MgO}, \mathrm{SrTiO}_{3}$, and $\mathrm{V}_{2} \mathrm{O}_{5}$ exhibit reproducible resistive switching properties [3-7]. Among them, $\mathrm{V}_{2} \mathrm{O}_{5}$ exhibits a metal-insulator transition (MIT) at a relatively low temperature of $280^{\circ} \mathrm{C}$. During the MIT process, the crystal structure, optical parameters, and conductivity of $\mathrm{V}_{2} \mathrm{O}_{5}$ change significantly. Therefore, $\mathrm{V}_{2} \mathrm{O}_{5}$ has potential applications for RRAMs [8]. On the other hand, $\mathrm{Sm}_{2} \mathrm{O}_{3}$, one of the rare earth oxides (REOs), has a large energy band gap, high thermal stability, good chemical stability, good thermal stability, low leakage current density, high breakdown electric field, and low trapping rates. Because of these superior properties, $\mathrm{Sm}_{2} \mathrm{O}_{3}$ has been investigated as a high-k material which could replace $\mathrm{SiO}_{2}$ in Complementary Metal-Oxide-Semiconductor (CMOS) devices [9-13]. There are two different resistive switch behaviors in RRAMs: unipolar resistive switching (URS) behavior and bipolar resistive switching (BRS) behavior [14]. Generally, BRS features faster switching speed, lower operation power, and better endurance than URS [15], while URS has a higher Resistance OFF/ON ( $\left.\mathrm{R}_{\mathrm{OFF}} / \mathrm{R}_{\mathrm{ON}}\right)$ ratio, easy reading operation, and higher memory density [16]. 
In this work, the resistive switching characteristics of RRAMs containing $\mathrm{Sm}_{2} \mathrm{O}_{3} / \mathrm{V}_{2} \mathrm{O}_{5}$ bilayer films were investigated. The effects of the $\mathrm{Sm}_{2} \mathrm{O}_{3}$ and $\mathrm{V}_{2} \mathrm{O}_{5}$ film stacking sequence on the switching behavior were also discussed. It would be advantageous to develop scalable RRAM devices exhibiting both bipolar and unipolar switching behaviors.

\section{Experimental}

In this work, four different kinds of RRAM structures were made. The first RRAM structure was a $\mathrm{V}_{2} \mathrm{O}_{5} / \mathrm{TiN} / \mathrm{SiO}_{2} / \mathrm{Si}$ substrate where a $\mathrm{V}_{2} \mathrm{O}_{5}$ film was deposited by radio frequency (RF) magnetron sputtering at room temperature (RT). A two-inch $\mathrm{V}_{2} \mathrm{O}_{5}$ target for the $\mathrm{V}_{2} \mathrm{O}_{5}$ sputtering deposition was made through a ceramic powder process, as described in our previous work [17]. The sputtering conditions for the $\mathrm{V}_{2} \mathrm{O}_{5}$ film deposition were an RF power of $75 \mathrm{~W}$ and an argon working pressure of $30 \mathrm{mTorr}$ for $10 \mathrm{~min}$. The second structure was a $\mathrm{Sm}_{2} \mathrm{O}_{3} / \mathrm{TiN} / \mathrm{SiO}_{2} / \mathrm{Si}$ substrate where a $\mathrm{Sm}_{2} \mathrm{O}_{3}$ film was deposited by RF magnetron sputtering at RT. The sputtering conditions for the $\mathrm{Sm}_{2} \mathrm{O}_{3}$ film deposition were an RF power of $85 \mathrm{~W}$ and an argon working pressure of $30 \mathrm{mTorr}$ at an oxygen to argon ratio of 1:10 for $5 \mathrm{~min}$. The third structure was a $\mathrm{Sm}_{2} \mathrm{O}_{3} / \mathrm{V}_{2} \mathrm{O}_{5} / \mathrm{TiN} / \mathrm{SiO}_{2} / \mathrm{Si}$ substrate where $\mathrm{V}_{2} \mathrm{O}_{5}$ and $\mathrm{Sm}_{2} \mathrm{O}_{3}$ films were deposited by RF magnetron sputtering at RT, as shown in Figure 1a. The fourth RRAM structure was a $\mathrm{V}_{2} \mathrm{O}_{5} / \mathrm{Sm}_{2} \mathrm{O}_{3} / \mathrm{TiN} / \mathrm{SiO}_{2} / \mathrm{Si}$ substrate where $\mathrm{Sm}_{2} \mathrm{O}_{3}$ and $\mathrm{V}_{2} \mathrm{O}_{5}$ films were deposited by RF magnetron sputtering at RT, as shown in Figure $1 \mathrm{~b}$.

An array of circular Al top contacts with a diameter of $50 \mu \mathrm{m}$ and a thickness of $200 \mathrm{~nm}$ was deposited by RF magnetron sputtering to form the Metal-Insulator-Metal (MIM) structure for the RRAMs. An Agilent 4156C semiconductor parameter analyzer was used to measure the resistive switching characteristics of the four different RRAM devices at RT. Positive sweep is defined as current that flows from the top to the bottom electrode. During the current-voltage $(I-V)$ measurements of the RRAM devices, the bias voltage was applied to the $\mathrm{Al}$ top electrode (TE) while the bottom electrode (BE) was grounded. The $I-V$ characteristics of the RRAM devices were obtained through DC voltage sweep measurements. A forming process is needed at the beginning to activate the resistive switching (RS) behavior by applying positive and negative biases.

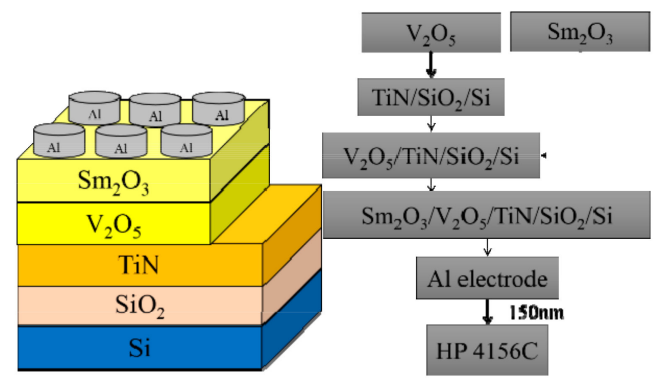

(a)

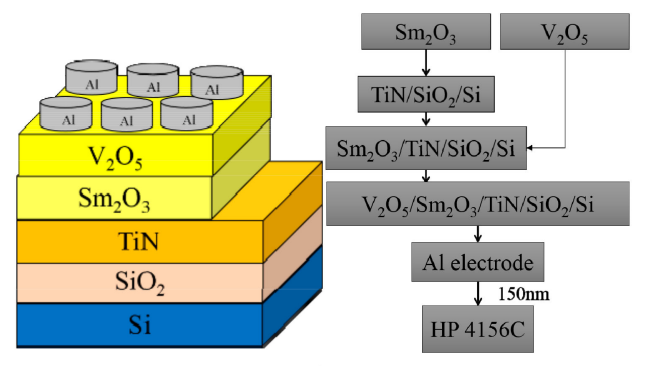

(b)

Figure 1. (a) The structure and deposition process of the $\mathrm{Al} / \mathrm{Sm}_{2} \mathrm{O}_{3} / \mathrm{V}_{2} \mathrm{O}_{5} / \mathrm{TiN} / \mathrm{SiO}_{2} / \mathrm{Si}$ device. (b) The structure and deposition process of the $\mathrm{Al} / \mathrm{V}_{2} \mathrm{O}_{5} / \mathrm{Sm}_{2} \mathrm{O}_{3} / \mathrm{TiN} / \mathrm{SiO}_{2} / \mathrm{Si}$ device.

\section{Results and Discussion}

Typical bipolar resistive switching $I-V$ curves for the $\mathrm{Sm}_{2} \mathrm{O}_{3}$ and $\mathrm{V}_{2} \mathrm{O}_{5}$ thin film RRAM devices are shown in Figure 2, and their bipolar switching characteristics were stable. Reproducible BRS behavior for the single-layer memory devices used in the initial electrical forming process was observed for the $\mathrm{Al} / \mathrm{Sm}_{2} \mathrm{O}_{3} / \mathrm{TiN} / \mathrm{SiO}_{2} / \mathrm{Si}$ and $\mathrm{Al} / \mathrm{V}_{2} \mathrm{O}_{5} / \mathrm{TiN} / \mathrm{SiO}_{2} / \mathrm{Si}$ structures shown in the insert in Figure 2 . The bias voltage was applied under the sweeping sequence of $1 \rightarrow 2 \rightarrow 3 \rightarrow 4$. In some studies, it has been observed that $\mathrm{Sm}_{2} \mathrm{O}_{3}$ and $\mathrm{V}_{2} \mathrm{O}_{5}$ thin films have polycrystalline structures. Oxygen vacancies easily drift through grain boundaries and dislocations, resulting in stable resistive switching behavior [7-10]. In studies of vanadium oxide films, it has been observed that these films have a stable reversible switching characteristic, and the current can be controlled by setting the current limit during the 
set process to reduce the power consumption [8]. Therefore, the second RRAM, which contains $\mathrm{Al} / \mathrm{V}_{2} \mathrm{O}_{5} / \mathrm{TiN} / \mathrm{SiO}_{2} / \mathrm{Si}$, was examined to study the effects of $\mathrm{V}_{2} \mathrm{O}_{5}$. A typical bipolar resistive switching $I-V$ curve for the $\mathrm{Al} / \mathrm{V}_{2} \mathrm{O}_{5} / \mathrm{TiN} / \mathrm{SiO}_{2} / \mathrm{Si}$ device is also shown in Figure 2, and the bipolar switching characteristic was stable. Figure 2 shows that both the $\mathrm{Al} / \mathrm{Sm}_{2} \mathrm{O}_{3} / \mathrm{TiN} / \mathrm{SiO}_{2} / \mathrm{Si}$ and $\mathrm{Al} / \mathrm{V}_{2} \mathrm{O}_{5} / \mathrm{TiN} / \mathrm{SiO}_{2} / \mathrm{Si}$ devices exhibited BRS behavior. As shown in Figure 2, the $\mathrm{Al} / \mathrm{Sm}_{2} \mathrm{O}_{3} / \mathrm{TiN} / \mathrm{SiO}_{2} / \mathrm{Si}$ device had a larger $\mathrm{R}_{\mathrm{HRS}} / \mathrm{R}_{\mathrm{LRS}}$ ratio than the $\mathrm{Al} / \mathrm{V}_{2} \mathrm{O}_{5} / \mathrm{TiN} / \mathrm{SiO}_{2} / \mathrm{Si}$ device. In addition, the reproducible BRS behavior of the $\mathrm{Sm}_{2} \mathrm{O}_{3}$ thin film RRAM device was low, and became progressively lower in the case of $\mathrm{V}_{2} \mathrm{O}_{5}$ thin films. For the $\mathrm{Sm}_{2} \mathrm{O}_{3}$ thin film RRAM devices, this effect might be caused by the high $\mathrm{R}_{\mathrm{LRS}} / \mathrm{R}_{\mathrm{HRS}}$ resistance values of the $\mathrm{V}_{2} \mathrm{O}_{5}$ thin film RRAM devices, leading to defects and dangling bonds. To further investigate and discuss the electrical conduction mechanism in the initial metallic filament forming process, the hopping conduction mechanism and Schottky emission conduction were inferred by $\ln I-V$ and $\ln I-V^{1 / 2}$ curve fitting $[18,19]$. For hopping conduction,

$$
J=q N_{a} v_{0} e^{-q \Phi_{T} / k T} e^{q a V / 2 d k T},
$$

where $N, a, \Phi_{T}, v_{0}$, and $d$ are the density of space charge, mean of hopping distance, barrier height of hopping, intrinsic vibration frequency, and film thickness, respectively. To validate the $\ln I-V$ curve fitting, the hopping conduction equation was transformed to the straight line representation of the equation: $\frac{\partial \log I}{\partial\left(\frac{1}{K T}\right)}=\mathrm{E}_{C}-\mathrm{E}_{F}-\mathrm{qV}_{A} \frac{\Delta z}{2 \mathrm{u}_{a}}$. The electronic activation energy barrier equation $(E a)$ and the hopping conduction distance $(\Delta z)$ extraction were observed [20].

For the Schottky emission equation,

$$
J=A^{*} T^{2} \exp \left[-q\left(\Phi_{B}-\sqrt{\frac{q E_{i}}{4 \pi \varepsilon_{i}}}\right) / k T\right]
$$

$T$ is the absolute temperature, $\Phi_{B}$ is the Schottky barrier height, $\varepsilon_{i}$ is the insulator permittivity, $k$ is Boltzmann's constant, and $A^{*}$ is the Richardson constant. To validate the $\ln \left(\frac{I}{T_{2}}\right)-\sqrt{V}$ curve fitting, the Schottky conduction equation was transformed to: $\ln \left(\frac{I}{T_{2}}\right)=\frac{q \sqrt{q / 4 \pi \varepsilon_{i} d}}{k T}$, where $\left(\frac{q \sqrt{q / 4 \pi \varepsilon_{i} d}}{k T}\right)$ is the slope and $\left(\frac{q \Phi_{B}}{k T}\right)$ is the intercept of the straight line equation [21].

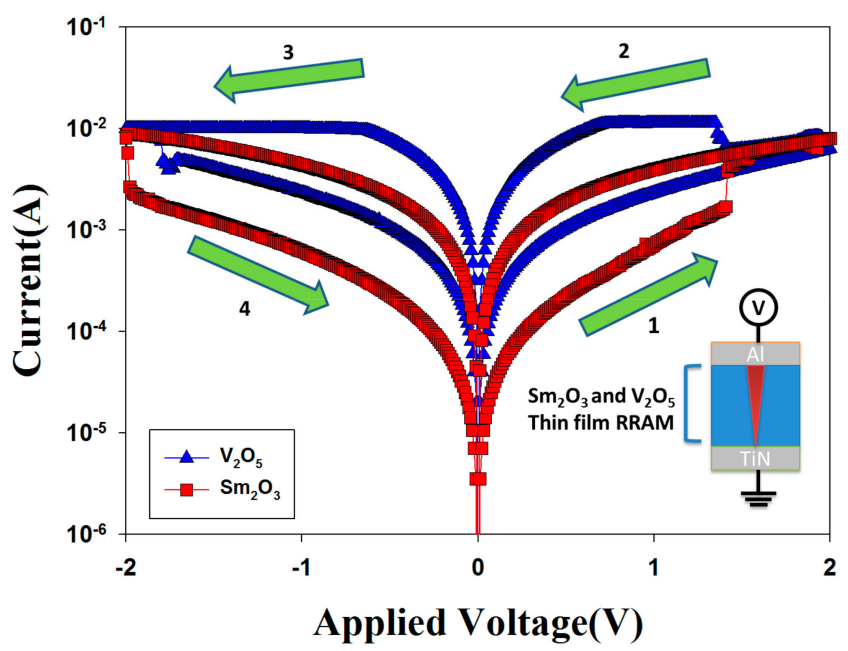

Figure 2. The current-voltage $(I-V)$ curves of the self-compliant $\mathrm{Sm}_{2} \mathrm{O}_{3}$ and $\mathrm{V}_{2} \mathrm{O}_{5}$ thin film resistive random access memory (RRAM) structure devices during the set/reset process.

The electrical conduction mechanisms of the $\mathrm{Sm}_{2} \mathrm{O}_{3}$ and $\mathrm{V}_{2} \mathrm{O}_{5}$ thin film RRAM devices during the set/reset process for positive and negative biases are shown in Figures 3 and 4 . For the $\mathrm{Sm}_{2} \mathrm{O}_{3}$ and $\mathrm{V}_{2} \mathrm{O}_{5}$ thin films with a voltage bias applied, the electrical conduction mechanisms exhibited the hopping 
conduction and Schottky emission mechanisms, as shown by the $\ln I-V$ and $\ln I-V^{1 / 2}$ curve fittings. The initial metal filament path processes and electrical conduction models for the $\mathrm{Al} / \mathrm{Sm}_{2} \mathrm{O}_{3} / \mathrm{TiN} / \mathrm{SiO} \mathrm{O}_{2} / \mathrm{Si}$ and $\mathrm{Al} / \mathrm{V}_{2} \mathrm{O}_{5} / \mathrm{TiN} / \mathrm{SiO}_{2} / \mathrm{Si}$ structures are shown in the insets of Figure $4 \mathrm{a}-\mathrm{d}$. In the hopping conduction mechanism, as seen from the $\ln I-V$ curve fitting in the initial metallic filament process of RRAM devices, the shallow trapped electrons jumped the activation energy barrier and induced a reduction of the leakage current. In the $\mathrm{Al} / \mathrm{V}_{2} \mathrm{O}_{5} / \mathrm{TiN} / \mathrm{SiO}_{2} / \mathrm{Si}$ structure, the $I-V$ curves exhibited the hopping conduction mechanism for low applied voltage biases and Schottky emission conduction for high applied voltage biases. In addition, the $\mathrm{Al} / \mathrm{Sm}_{2} \mathrm{O}_{3} / \mathrm{TiN} / \mathrm{SiO}_{2} / \mathrm{Si} \mathrm{RRAM}$ structures exhibited self-compliance properties and similar electrical conduction mechanisms to the $\mathrm{V}_{2} \mathrm{O}_{5}$ thin film RRAM shown in Figure 4.
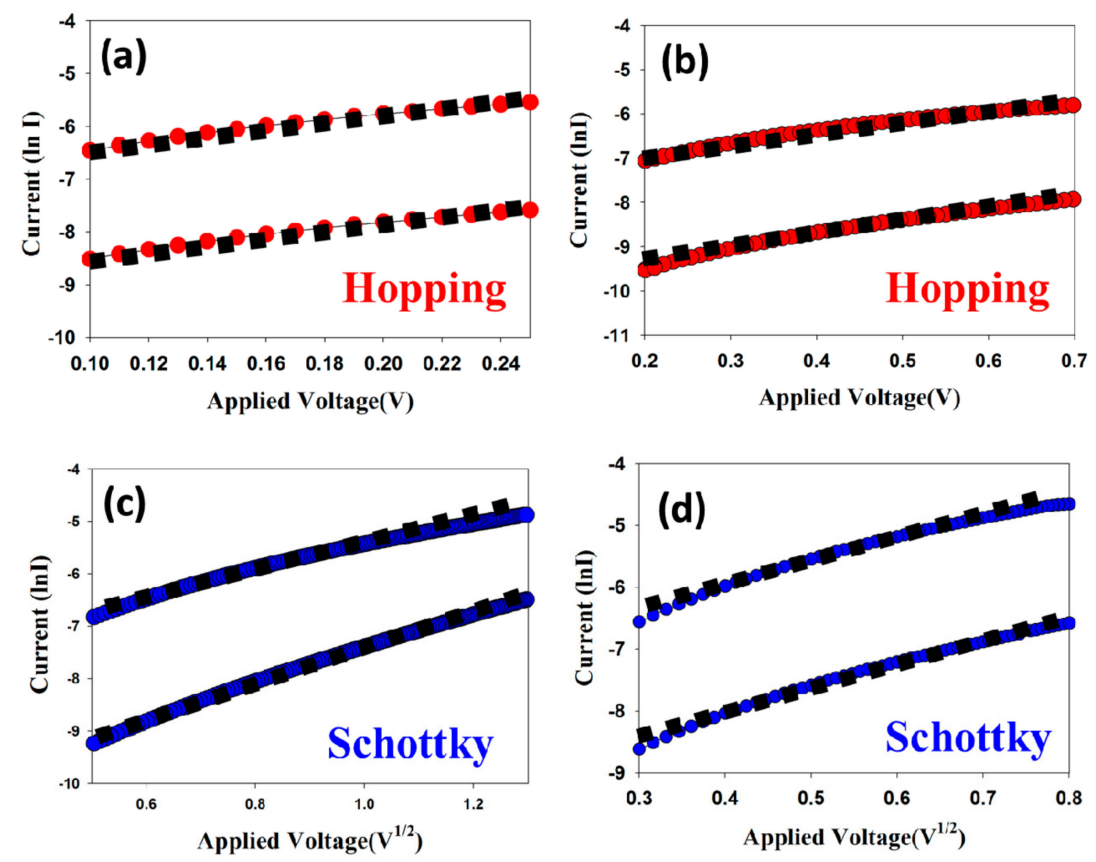

Figure 3. The $\ln I-V$ and $\ln I-V^{1 / 2}$ curve fittings for the hopping conduction mechanism for $(\mathbf{a}) \mathrm{V}_{2} \mathrm{O}_{5}$ and (b) $\mathrm{Sm}_{2} \mathrm{O}_{3}$ memory devices for the ON/OFF state. The Schottky emission conduction of the (c) $\mathrm{V}_{2} \mathrm{O}_{5}$ thin films and (d) $\mathrm{Sm}_{2} \mathrm{O}_{3}$ memory devices for the ON/OFF state.
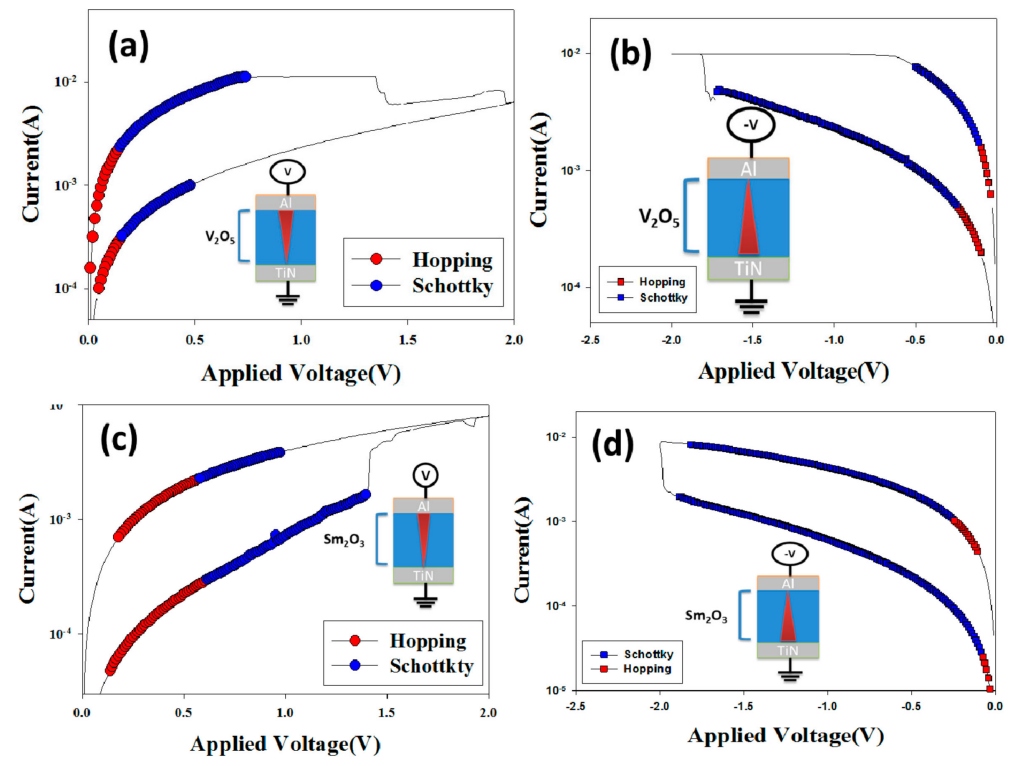

Figure 4. The electrical conduction mechanism and metal filament path model of the self-compliant $\mathrm{Sm}_{2} \mathrm{O}_{3}$ and non-compliant $\mathrm{V}_{2} \mathrm{O}_{5}$ thin film RRAM devices for positive and negative biases. 
From Figures 2-4, we can see that both the $\mathrm{Al} / \mathrm{Sm}_{2} \mathrm{O}_{3} / \mathrm{TiN} / \mathrm{SiO}_{2} / \mathrm{Si}$ and $\mathrm{Al} / \mathrm{V}_{2} \mathrm{O}_{5} / \mathrm{TiN} / \mathrm{SiO}_{2} / \mathrm{Si}$ devices exhibited bipolar resistive switching behavior. Therefore, in the third RRAM device structure we combined $\mathrm{Sm}_{2} \mathrm{O}_{3}$ and $\mathrm{V}_{2} \mathrm{O}_{5}$ films to study the effects of this on the resistive switching behavior of the RRAMs.

Typical bipolar resistive switching $I-V$ curves for the $\mathrm{Al} / \mathrm{V}_{2} \mathrm{O}_{5} / \mathrm{Sm}_{2} \mathrm{O}_{3} / \mathrm{TiN} / \mathrm{SiO}_{2} / \mathrm{Si}$ and $\mathrm{Al} / \mathrm{Sm}_{2} \mathrm{O}_{3} / \mathrm{V}_{2} \mathrm{O}_{5} / \mathrm{TiN} / \mathrm{SiO}_{2} / \mathrm{Si}$ devices are shown in Figure 5 , and the bipolar switching characteristic was stable. However, the forming voltage of the device containing a $\mathrm{V}_{2} \mathrm{O}_{5} / \mathrm{Sm}_{2} \mathrm{O}_{3}$ bilayer was higher than that of the devices containing a single layer of $\mathrm{V}_{2} \mathrm{O}_{5}$ or $\mathrm{Sm}_{2} \mathrm{O}_{3}$. On the other hand, the $\mathrm{R}_{\mathrm{HRS}} / \mathrm{R}_{\mathrm{LRS}}$ ratio of the device containing a $\mathrm{V}_{2} \mathrm{O}_{5} / \mathrm{Sm}_{2} \mathrm{O}_{3}$ bilayer was one order of magnitude higher than that of the devices containing a single layer of $\mathrm{V}_{2} \mathrm{O}_{5}$ or $\mathrm{Sm}_{2} \mathrm{O}_{3}$. In addition, the self-compliance and non-compliance properties of the $\mathrm{Al} / \mathrm{Sm}_{2} \mathrm{O}_{3} / \mathrm{V}_{2} \mathrm{O}_{5} / \mathrm{TiN} / \mathrm{SiO}_{2} / \mathrm{Si}$ and $\mathrm{Al} / \mathrm{V}_{2} \mathrm{O}_{5} / \mathrm{Sm}_{2} \mathrm{O}_{3} / \mathrm{TiN} / \mathrm{SiO}_{2} / \mathrm{Si}$ structures are shown in Figure 5.

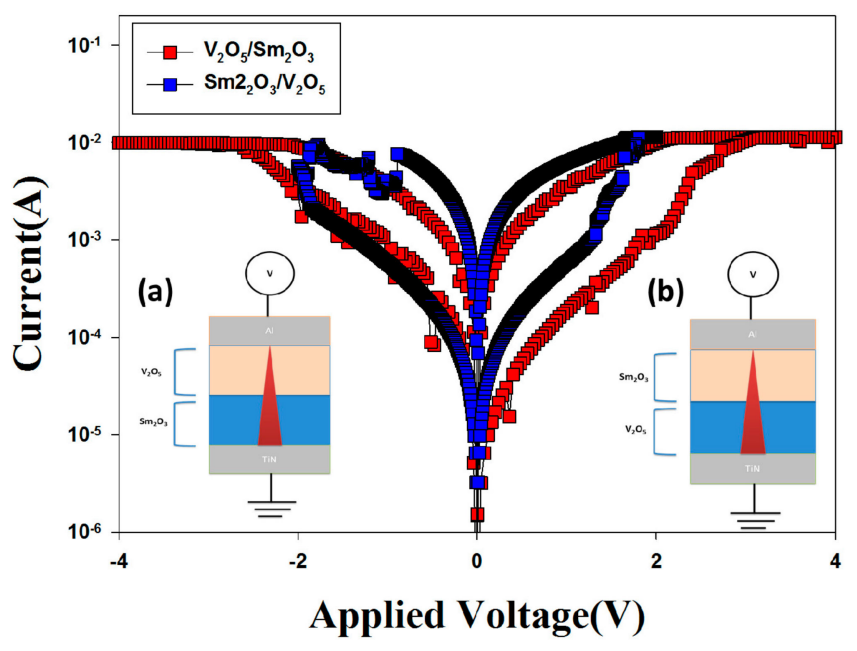

Figure 5. The resistive switching characteristics of the $\mathrm{Al} / \mathrm{V}_{2} \mathrm{O}_{5} / \mathrm{Sm}_{2} \mathrm{O}_{3} / \mathrm{TiN} / \mathrm{SiO}_{2} / \mathrm{Si}$ and $\mathrm{Al} / \mathrm{Sm}_{2} \mathrm{O}_{3} / \mathrm{V}_{2} \mathrm{O}_{5} / \mathrm{TiN} / \mathrm{SiO}_{2} / \mathrm{Si}$ memory devices.

For the fourth RRAM device, $\mathrm{Al} / \mathrm{Sm}_{2} \mathrm{O}_{3} / \mathrm{V}_{2} \mathrm{O}_{5} / \mathrm{TiN} / \mathrm{SiO}_{2} / \mathrm{Si}$, the stacking sequence of the $\mathrm{V}_{2} \mathrm{O}_{5}$ and $\mathrm{Sm}_{2} \mathrm{O}_{3}$ films were exchanged. A typical unipolar resistive switching $I-V$ curve for the $\mathrm{Al} / \mathrm{Sm}_{2} \mathrm{O}_{3} / \mathrm{V}_{2} \mathrm{O}_{5} / \mathrm{TiN} / \mathrm{SiO}_{2} / \mathrm{Si}$ device is shown in Figure 5. In this experiment, we found that the stacking sequence of the $\mathrm{Sm}_{2} \mathrm{O}_{3}$ and $\mathrm{V}_{2} \mathrm{O}_{5}$ films in the bilayer structure can affect the switching features of the RRAM, causing either BRS behavior or URS behavior. It was also shown that the reset process of this device displays a shrinking phenomenon compared to that of the $\mathrm{Al} / \mathrm{V}_{2} \mathrm{O}_{5} / \mathrm{Sm}_{2} \mathrm{O}_{3} / \mathrm{TiN} / \mathrm{SiO}_{2} / \mathrm{Si}$ device.

In Figure 6, the electrical conduction mechanisms of the $\mathrm{Al} / \mathrm{Sm}_{2} \mathrm{O}_{3} / \mathrm{V}_{2} \mathrm{O}_{5} / \mathrm{TiN} / \mathrm{SiO}_{2} / \mathrm{Si}$ and $\mathrm{Al} / \mathrm{V}_{2} \mathrm{O}_{5} / \mathrm{Sm}_{2} \mathrm{O}_{3} / \mathrm{TiN} / \mathrm{SiO}_{2} / \mathrm{Si}$ thin film RRAM devices during the set/reset process for positive and negative bias are shown. In the $\mathrm{Al} / \mathrm{Sm}_{2} \mathrm{O}_{3} / \mathrm{V}_{2} \mathrm{O}_{5} / \mathrm{TiN} / \mathrm{SiO}_{2} / \mathrm{Si}$ structure, the electrical conduction exhibited the hopping conduction mechanism, as can be seen by the $\ln I-V$ curve fitting. The $\ln I-V^{1 / 2}$ curve fitting and the $I-V$ curve for the $\mathrm{Al} / \mathrm{Sm}_{2} \mathrm{O}_{3} / \mathrm{V}_{2} \mathrm{O}_{5} / \mathrm{TiN} / \mathrm{SiO}_{2} / \mathrm{Si}$ structure exhibited the hopping conduction mechanism in the initial metallic filament process of the RRAM device. Based on the above results obtained in dual-layer structure RRAM devices, we suggest that $\mathrm{Sm}_{2} \mathrm{O}_{3}$ thin films play an important role because of the leakage current lowering properties of shallow trapped electrons jumping the activation energy barrier [11]. 


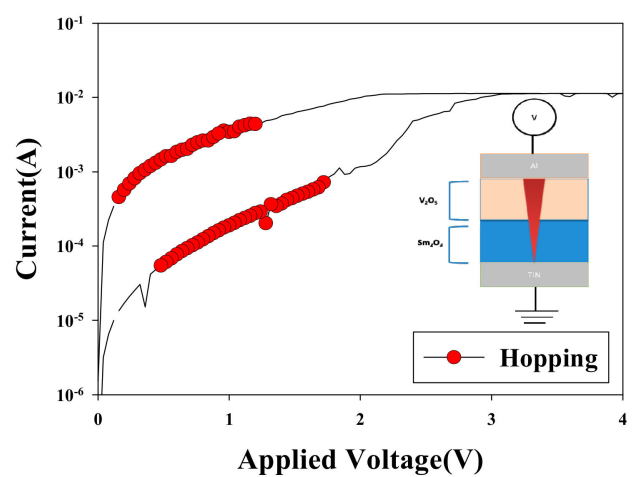

(a)

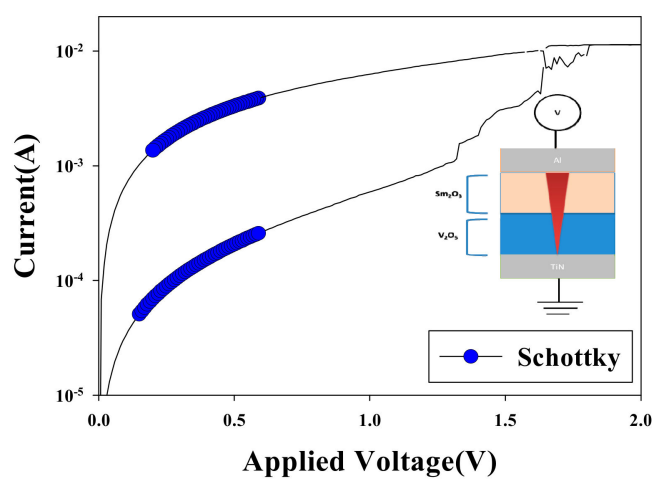

(b)

Figure 6. The electrical conduction mechanisms and metal filament path models for the $\mathrm{Al} / \mathrm{Sm}_{2} \mathrm{O}_{3} / \mathrm{V}_{2} \mathrm{O}_{5} / \mathrm{TiN} / \mathrm{SiO}_{2} / \mathrm{Si}$ and $\mathrm{Al} / \mathrm{V}_{2} \mathrm{O}_{5} / \mathrm{Sm}_{2} \mathrm{O}_{3} / \mathrm{TiN} / \mathrm{SiO}_{2} / \mathrm{Si}$ devices when a positive bias is applied.

Figure 7 shows the initial metallic filament path forming model and the hopping conduction mechanism of the $\mathrm{Al} / \mathrm{V}_{2} \mathrm{O}_{5} / \mathrm{Sm}_{2} \mathrm{O}_{3} / \mathrm{TiN} / \mathrm{SiO}_{2} / \mathrm{Si}$ structure for the ON/OFF state. In Figure $7 \mathrm{a}$, the initial metallic filament path forming for the RRAM device for an applied positive bias in the set state is shown. In Figure $7 b$, the metallic filament is slightly thinner because of the continuous oxidation reaction by oxygen atoms from the metal oxide bonds on the interface of the $\mathrm{Sm}_{2} \mathrm{O}_{3} / \mathrm{TiN}$ electrode.

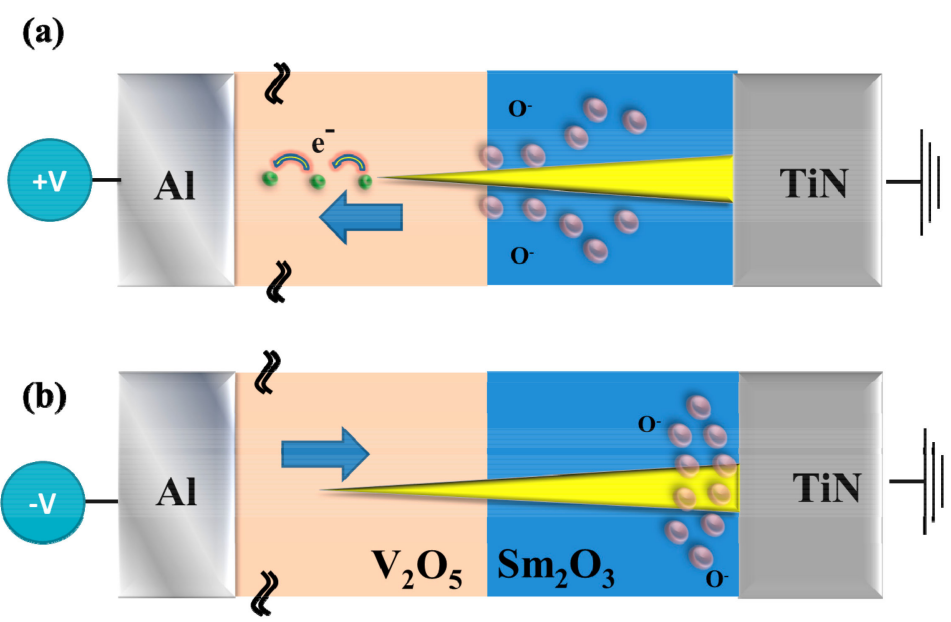

Figure 7. The electrical transfer mechanisms and initial metallic filament path models for the $\mathrm{Al} / \mathrm{V}_{2} \mathrm{O}_{5} / \mathrm{Sm}_{2} \mathrm{O}_{3} / \mathrm{TiN} / \mathrm{SiO}_{2} / \mathrm{Si}$ and $\mathrm{Al} / \mathrm{Sm}_{2} \mathrm{O}_{3} / \mathrm{V}_{2} \mathrm{O}_{5} / \mathrm{TiN} / \mathrm{SiO}_{2} / \mathrm{Si}$ devices in the ON/OFF state for the (a) $\mathrm{ON}$ and (b) OFF states.

To discuss the excellent nonvolatile random memory devices properties, the switching cycling reliability and retention time characteristic measurements for the $\mathrm{Al} / \mathrm{V}_{2} \mathrm{O}_{5} / \mathrm{Sm}_{2} \mathrm{O}_{3} / \mathrm{TiN} / \mathrm{SiO} / 2 \mathrm{Si} \mathrm{RRAM}$ device are shown in Figure 8 . For switching cycling reliability, the $\mathrm{R}_{\mathrm{HRS}} / \mathrm{R}_{\mathrm{LRS}}$ ratio was approximately $10^{3}$. In another nonvolatile memory characteristic calculation, significant and apparently stable ON/OFF characteristics for different retention times in $\mathrm{Al} / \mathrm{V}_{2} \mathrm{O}_{5} / \mathrm{Sm}_{2} \mathrm{O}_{3} / \mathrm{TiN} / \mathrm{SiO}_{2} / \mathrm{Si}$ RRAM devices for HRS/LRS were also observed. 


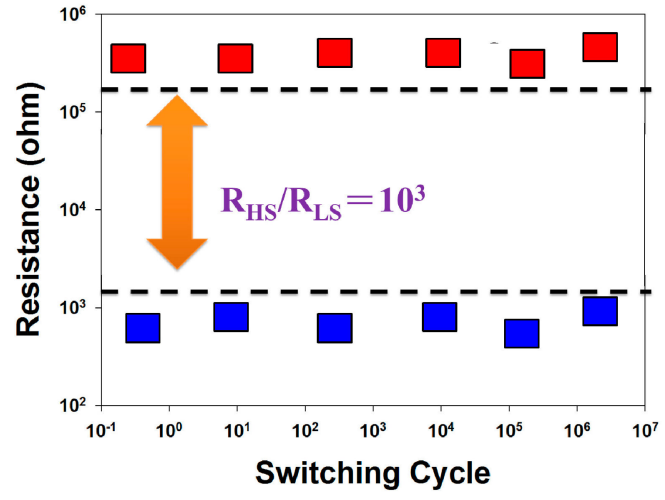

(a)

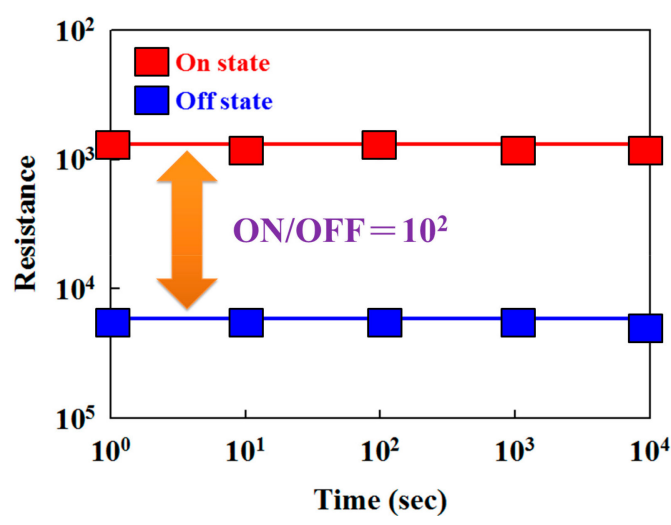

(b)

Figure 8. (a) Endurance cycle and (b) retention time properties of the $\mathrm{Al} / \mathrm{V}_{2} \mathrm{O}_{5} / \mathrm{Sm}_{2} \mathrm{O}_{3} / \mathrm{TiN} / \mathrm{SiO}_{2} / \mathrm{Si}$ devices at room temperature, as measured at $0.2 \mathrm{~V}$.

\section{Conclusions}

In this study, the resistive switching characteristics of RRAM devices with integrated $\mathrm{Sm}_{2} \mathrm{O}_{3}$ and $\mathrm{V}_{2} \mathrm{O}_{5}$ films were investigated. All four of the RRAM structures constructed in this work showed stable resistive switching behaviors. The $\mathrm{R}_{\mathrm{HRS}} / \mathrm{R}_{\mathrm{LRS}}$ ratio of the RRAM device containing a $\mathrm{V}_{2} \mathrm{O}_{5} / \mathrm{Sm}_{2} \mathrm{O}_{3}$ bilayer was higher than those of the devices containing a single layer of $\mathrm{V}_{2} \mathrm{O}_{5}$ or $\mathrm{Sm}_{2} \mathrm{O}_{3}$. It was found that the stacking sequence of the $\mathrm{Sm}_{2} \mathrm{O}_{3}$ and $\mathrm{V}_{2} \mathrm{O}_{5}$ films in the bilayer structure can affect the switching feature of the RRAM, leading to either BRS behavior or URS behavior. Hence, it would be beneficial to develop scalable RRAM devices that exhibit both bipolar and unipolar switching behaviors to expand their applications to nonvolatile memories.

Author Contributions: Data curation, J.-Y.L.; Resources, J.-Y.L. and K.-H.C.; Supervision, J.-Y.L. and K.-H.C.; Writing—review \& editing, J.-Y.L. and K.-H.C.; Methodology, K.-H.C.; Formal analysis, K.-Y.W.; Investigation, K.-Y.W.; Writing-original draft, K.-Y.W.

Funding: This research received no external funding.

Acknowledgments: I would like to thank Chien-Min Cheng's laboratory at Southern Taiwan University of Science and Technology, and Ying-Jie Chen for their help. This work has been supported by the Ministry of Science and Technology of the Republic of China under Contract No. MOST107-2622-E-224-016-CC3.

Conflicts of Interest: There is no conflict of interest in this experiment.

\section{References}

1. Murali, S.; Rajachidambaram, J.S.; Han, S.Y.; Chang, C.H.; Herman, G.S.; Conley, J.F., Jr. Resistive switching in zinc-tin-oxide. Solid State Electron. 2013, 79, 248-252. [CrossRef]

2. Ismail, M.; Talib, I.; Rana, A.M.; Ahmad, E.; Nadeem, M.Y. Performance stability and functional reliability in bipolar resistive switching of bilayer ceria based resistive random access memory devices. J. Appl. Phys. 2015, 117, 084502. [CrossRef]

3. Liang, D.; Li, X.; Wang, J.; Wu, L.; Chen, P. Light-controlled resistive switching characteristics in $\mathrm{ZnO} / \mathrm{BiFeO}_{3} / \mathrm{ZnO}$ thin film. Solid State Electron. 2018, 145, 46-48. [CrossRef]

4. Cheng, C.H.; Chou, K.I.; Zheng, Z.W.; Hsu, H.H. Low power resistive random access memory using interface engineered dielectric stack of $\mathrm{SiO}_{x} / \mathrm{a}-\mathrm{Si} / \mathrm{TiOy}$ with 1D1R-like structure. Curr. Appl. Phys. 2014, 14, 139-143. [CrossRef]

5. Guo, J.; Ren, S.; Wu, L.; Kang, X.; Chena, W.; Zhao, X. Low power, high uniform, and forming-free resistive memory based on Mg-deficient amorphous $\mathrm{MgO}$ film with rough surface. Appl. Surf. Sci. 2018, 434, 1074-1078. [CrossRef] 
6. Pan, X.; Shuai, Y.; Wu, C.; Luo, W.; Sun, X.; Yuan, Y.; Zhou, S.; Ou, X.; Zhang, W. Resistive switching behavior in single crystal $\mathrm{SrTiO}_{3}$ annealed by laser. Appl. Surf. Sci. 2016, 389, 1104-1107. [CrossRef]

7. Xu, D.; Xiong, Y.; Tang, M.; Zeng, B. Coexistence of the bipolar and unipolar resistive switching behaviors in vanadium doped ZnO films. J. Alloy. Compd. 2014, 584, 269-272. [CrossRef]

8. Xiaoying, W.; Ming, H.; Kailiang, Z.; Fang, W.; Kai, L. Study on microstructure and resistance characteristic of vanadium oxide thin films. Acta Phys. Sin. 2013, 62, 47-201.

9. Pan, T.M.; Lu, C.H. Switching behavior in rare-earth films fabricated in full room temperature. IEEE Trans. Electron Devices 2012, 59, 956-961. [CrossRef]

10. Manjunath, V.; Reddy, V.R.; Reddy, P.R.S.; Janardhanam, V.; Choi, C.J. Electrical and frequency-dependent properties of $\mathrm{Au} / \mathrm{Sm}_{2} \mathrm{O}_{3} / \mathrm{n}$-GaN MIS junction with a high-k rare earth $\mathrm{Sm}_{2} \mathrm{O}_{3}$ as interlayer. Curr. Appl. Phys. 2017, 17, 980-988. [CrossRef]

11. Karpov, V.G.; Niraula, D. OFF State Conduction in Filamentary RRAM. IEEE Trans. Electron Devices Lett. 2019, 40, 550-553. [CrossRef]

12. Chin, W.C.; Cheong, K.Y.; Hassan, Z. $\mathrm{Sm}_{2} \mathrm{O}_{3}$ gate dielectric on Si substrate. Mater. Sci. Semicon. Process. 2010, 13, 303-314. [CrossRef]

13. Sen, B.; Wong, H.; Molina, J.; Iwai, H.; Ng, J.A.; Kakushima, K.; Sarkar, C.K. Trapping characteristics of lanthanum oxide gate dielectric film explored from temperature dependent current-voltage and capacitance-voltage measurements. Solid State Electron. 2007, 51, 475-480. [CrossRef]

14. Choi, J.S.; Kim, J.S.; Hwang, I.R.; Hong, S.H.; Jeon, S.H.; Kang, S.O.; Park, B.H.; Kim, D.C.; Lee, M.J.; $\mathrm{Seo}, \mathrm{S}$. Different resistance switching behaviors of $\mathrm{NiO}$ thin films deposited on $\mathrm{Pt}$ and $\mathrm{SrRuO}_{3}$ electrodes. Appl. Phys. Lett. 2009, 95, 022109. [CrossRef]

15. Sun, X.; Li, G.; Zhang, X.; Ding, L.H.; Zhang, W.F. Coexistence of the bipolar and unipolar resistive switching behaviours in $\mathrm{Au} / \mathrm{SrTiO}_{3} / \mathrm{Pt}$ cells. J. Phys. D Appl. Phys. 2011, 44, 125-404. [CrossRef]

16. Chae, S.C.; Lee, J.S.; Kim, S.J.; Lee, S.B.; Chang, S.H.; Liu, C.; Kahng, B.; Shin, H.; Kim, D.W.; Shin, H.; et al. Random circuit breaker network model for unipolar resistance switching. Adv. Mater.. [CrossRef]

17. Lin, J.Y.; Wu, K.Y.; Chen, K.H.; Cheng, C.M.; Li, C.Y. Bipolar switching properties of bilayer $\mathrm{V}_{2} \mathrm{O}_{5} / \mathrm{Sm}_{2} \mathrm{O}_{3}$ thin-film resistive random access memory device prepared by sputtering technology. Sens. Mater. 2018, 30, 933-938.

18. Tsai, T.M.; Chang, K.C.; Chang, T.C.; Syu, Y.E.; Chuang, S.L. Low temperature improvement method on $\mathrm{Zn}: \mathrm{SiOx}$, resistive random access memory devices. IEEE Electron Device Lett. 2013, 34, 511-513.

19. Tsai, T.M.; Chang, K.C.; Chang, T.C.; Chang, G.W.; Syu, Y.E. Charge quantity influence on resistance switching characteristic during forming process. IEEE Electron Device Lett. 2013, 34, 502-504.

20. Chen, K.H.; Tsai, T.M.; Cheng, C.M.; Huang, S.J.; Chang, K.C.; Liang, S.P.; Young, T.F. Schottky emission distance and barrier height properties of bipolar switching Gd:SiOx RRAM devices under different oxygen concentration environments. Materials 2018, 11, 43. [CrossRef]

21. Chen, K.H.; Cheng, C.M.; Li, C.Y.; Huang, S.J. Hopping conduction distance of bipolar switching GdOx resistance random access memory thin films devices modified by different constant compliance current. Microelectron. Reliab. 2018, 91, 330-334. [CrossRef]

(C) 2019 by the authors. Licensee MDPI, Basel, Switzerland. This article is an open access article distributed under the terms and conditions of the Creative Commons Attribution (CC BY) license (http://creativecommons.org/licenses/by/4.0/). 